\title{
Competition Indices Identify Forb Species That Promote Overyielding of a Dominant Grass in Grassland Restoration
}

\author{
Drew A. Scott ${ }^{1}$ \\ ${ }^{1}$ Dep. of Plant Biology and Center for Ecology, Southern Illinois Univ. Carbondale, 1125 Lincoln Dr. Mailcode \\ 6509, Carbondale, IL 62901, USA \\ Correspondence: Drew Scott, Dep. of Plant Biology and Center for Ecology, Southern Illinois Univ. Carbondale, \\ 1125 Lincoln Dr. Mailcode 6509, Carbondale, IL 62901, USA. E-mail: dascott@ siu.edu
}

Received: December 9, 2019

Accepted: January 4, $2020 \quad$ Online Published: January 15, 2020

doi:10.5539/jps.v9n1p28

URL: https://doi.org/10.5539/jps.v9n1p28

\begin{abstract}
Overyielding is a common phenomenon. Overyielding of dominant grasses when in competition with common forbs during grassland restoration could lead to lower plant diversity. My objective was to characterize overyielding of Andropogon gerardii in competition with fcommon forbs. I collected soils representing different stages of restoration $(0,4$, and 16 years restored) and conducted a pairwise competition experiment with a dominant grass, Andropogon gerardii, in competition with four subordinate forbs (Oligoneuron rigidum L., Liatris punctata Hook, Lespedeza capitata Michx., or Desmanthus illinoensis Michx.). Relative yield indices (RY) were calculated by comparison with a two-individual monoculture of A. gerardii with both per grass biomass and per grass net absolute tiller appearance rate (TAR). Overyielding of $A$. gerardii was in competition with Oligoneuron rigidum was indicated by RY values (greater than1) using both biomass and TAR measurements. These findings suggest that $O$. rigidum should be given low priority for inclusion in tallgrass prairie restoration seed mixes.
\end{abstract}

Keywords: diversity, dominance, plant-plant interactions, tallgrass prairie

\section{Introduction}

Plant communities in grassland restorations undergo rapid changes (Manning \& Baer, 2018; Scott and Baer, 2019) coinciding with dynamically changing soil properties (Rosenzweig et al. 2016; Scott et al., 2017) and thus could change the cover of dominant grasses. Further, plant richness declines with grassland restoration age (Sluis, 2002; Camill et al., 2004; Hansen \& Gibson, 2014) due to increasing cover of dominant grasses. Whether overyielding (i.e. more biomass production in mixture relative to monoculture) of a dominant grass occurs during competition with forb species within grassland restoration remains unclear. In this follow up report to Scott \& Baer (2018), which described soil influence on performance of a dominant grass, I report on overyielding of dominant grass in competition with common forbs during tallgrass prairie restoration.

There is a great deal of empirical support for overyielding (Hector et al., 1999, Tilman et al., 2001; Loreau \& Hector, 2001). Overyielding is also expected to occur commonly and reach equilibrium quickly based on theoretical analyses (Beckage \& Gross, 2006). Because of this expectation, a way to screen for overyielding of a dominant grass when in competition with common forbs is useful for planning diverse grassland restorations.

The objective of this study was to determine if overyielding occurred when a dominant grass was in competition with a common forb in restored grassland soil. First, I sought to show that competition occurred during the experiment by comparing biomass of a single dominant grass, Andropogon gerardii, to a two-individual monoculture of A. gerardii. Then I tested if relative yield (RY) index values of A. gerardii were greater than 1 (indicating overyielding) for each forb competitor species. I hypothesized that A. gerardii would show overyielding when in competition with the 4 common forbs tested.

\section{Methods}

Soil sampling and seed collection was performed at Konza Prairie Long-Term Ecological Research (LTER) site located approximately $9 \mathrm{~km}$ southwest of Manhattan, Kansas $\left(39^{\circ} 050 \mathrm{~N}, 96^{\circ} 350 \mathrm{~W}\right)$. Mean annual precipitation is $835 \mathrm{~mm}$ and the average annual temperature is $12.7^{\circ} \mathrm{C}$, with hot summers and cold winters (NOAA/ESRA 2003). Fields were in cultivation for more than 50 years before restoration by hand broadcasting locally collected 
seed. Soils in these fields were classified as Reading silt loam soil formed from alluvial silt deposits, with $0-1 \%$ slopes (fine silt, mixed, superactive, and mesic Pachic Argiudoll; USDA Web Soil Survey; USDA 2014). Soils were sampled the following adjacent areas: a cultivated field (initial conditions of restoration), 4-y restored prairie, and 16-y restored prairie. Multiple soil restoration ages allowed us to make generalizations about competition during the process of grassland restoration.

Soil cores (7.62 cm diameter x $20 \mathrm{~cm}$ deep) were sampled with PVC coring devices in April 2014. Cores remained in the coring devices throughout the experiment to maintain soil structure. Coring devices containing intact soil cores were placed in the Horticultural Research Greenhouse at Southern Illinois University. Plants in this greenhouse experiment were grown from seed collected from native prairie near the restored soils. Soils were scarified to a depth of 2-4 mm before adding seeds. After 4 weeks, most seeds had germinated. The experiment was maintained for an additional 18 weeks. Greenhouse temperatures ranged from 15 to $30{ }^{\circ} \mathrm{C}$ with 15-h photoperiods (supplemental sodium halide lights). Soils were maintained at approximately field capacity by watering cores to saturation daily and allowing water to drain freely. Coring devices were evenly spaced throughout the 18-week greenhouse experiment to minimize shading of plants in other coring devices. Coring devices were spread over two greenhouse benches, with half of the soil restoration age by competitor species replicates on each bench. Light and water resources were provided in excess because I was interested in soil resources that dynamically change with restoration age.

Andropogon gerardii Vitman growing as single plants, in a two-individual monoculture of A. gerardii, and in 1:1 interspecific competition with common forbs (Oligoneuron rigidum L., Liatris punctata Hook, Lespedeza capitata Michx., or Desmanthus illinoensis Michx.) were used, with four replicates in each of the three soil restoration ages $(0,4$, or 16 years of restoration; taxonomy according to USDA plants database). Biomass of the single grass was subtracted from the per plant biomass of the two-individual monoculture of $A$. gerardii to validate our assumption that competition occurred. Multiple soil restoration ages were used because changes in soil microbial, nutrient, and structural conditions were previously detected (Table 1). Tiller (shoot grown after the parent shoot, which emerged from seed) abundances were measured weekly and used to calculate net tiller appearance rate (TAR). Aboveground biomass was collected at the end of the experiment, dried at $55{ }^{\circ} \mathrm{C}$, and weighed. Relative yield (a competition importance index) based on tillering rate or aboveground biomass was then calculated (de Wit 1960; $\mathrm{RY}_{\mathrm{a}, \mathrm{b}}=\mathrm{Y}_{\mathrm{mix}} / \mathrm{Y}_{\mathrm{mono}}$, with $d_{\mathrm{A}}=d_{\mathrm{a}}+d_{\mathrm{b}}$ ) as the quotient of per plant performance in mixture and monoculture, with equal densities in monoculture and mixture.

\subsection{Statistical Analyses}

All statistical analyses were performed in R (The R Foundation for Statistical Computing, 2017), with Welch $\mathrm{t}$-tests and one-sample t-tests performed in the package ggpubr (Kassambara, 2018). The alternative hypothesis that additional biomass in the single grass was greater than 0 , indicating competition occurred, was tested with Welch t-tests for each soil restoration age. This information was displayed in a box plot of restoration age with a global mean displayed.

Significant outliers (Grubbs test for each competitor species by soil age group after passing a Shakiro-Wilk test of normality) of relative yield based on biomass measurements $\left(\mathrm{RY}_{\text {biomass }}\right.$ and ( $\left.\mathrm{RY} \mathrm{T}_{\mathrm{TAR}}\right)$ were also treated as missing values. There were missing values because of plants that never emerged. I did not block by greenhouse bench because Welch t-tests indicated that there was no difference in means of $\mathrm{RY}_{\text {biomass }}\left(t_{37}=-0.84, P=0.4096\right)$ and $\mathrm{RY}_{\mathrm{TAR}}\left(t_{42}=0.72, P=0.477\right)$.

Possibility of A. gerardii overyielding when in competition with common forbs was evaluated by testing if $\mathrm{RY}_{\text {biomass }}$ and $\mathrm{RY}_{\mathrm{TAR}}>1$ in soils where evidence of competition was found. Relative yield values less than 1 lesser performance in mixture compared to monoculture; values greater than 1 indicate greater performance in mixture compared to monoculture (de Wit 1960; Weigelt \& Jolliffe 2003). This comparison was performed with one-sample t-tests for each forb competitor species. Boxplots were created for each forb competitor with a solid line at $\mathrm{RY}=1$.

\section{Results}

Per grass biomass was greater in single grass cores compared to two-grasses per core (Fig. 1), suggesting A. gerardii competition occurred under greenhouse conditions. Andropogon gerardii exhibited overyielding, as indicated by $\mathrm{RY}_{\text {biomass, }}$, with Liatris punctata (mean $=1.75, t_{10}=2.68, P=0.012$ ) and Oligoneuron rigidum (mean $=1.83, t_{10}=3.41, P=0.003$ ), but not Desmanthus illinoensis (mean $=0.96, t_{10}=-0.20, P=0.579$ ) and Lespedeza capitata (mean $=1.26, t_{11}=0.74, P=0.238$; Fig. 2). Andropogon gerardii exhibited overyielding, as indicated by $\mathrm{RY}_{\mathrm{TAR}}$, with Oligoneuron rigidum (mean $=2.45, t_{10}=2.68, P=0.012$ ), but not Desmanthus illinoensis $\left(\right.$ mean $\left.=1.27, t_{10}=0.75, P=0.235\right)$, Lespedeza capitata $\left(\right.$ mean $\left.=1.04, t_{10}=0.47, P=0.324\right)$, and 
Liatris punctata $\left(\right.$ mean $=2.46, t_{10}=1.80, P=0.051$; Fig. 3$)$.

Table 1. Differences in soil conditions among cultivated, 4 and 16 year restored prairie, modified from Scott \& Baer (2018)

\begin{tabular}{|c|c|c|c|c|c|c|c|c|c|c|c|c|c|}
\hline Soil Property & Age effect & \multicolumn{4}{|c|}{ Cultivated } & \multicolumn{4}{|c|}{4 y Restored } & \multicolumn{4}{|c|}{16 y Restored } \\
\hline PLFA Biomass (nmol/g) & $\begin{array}{l}F_{2,9}=6.27 \\
P=0.020\end{array}$ & 169.84 & \pm & 27.90 & A & 231.28 & \pm & 27.90 & A & 309.25 & \pm & 27.90 & B \\
\hline Plant-available N ( $\mu \mathrm{g} / \mathrm{g})$ & $\begin{array}{l}F_{2,9}=20.48 \\
P<0.001\end{array}$ & 8.21 & \pm & 0.76 & A & 1.95 & \pm & 0.76 & B & 2.56 & \pm & 0.76 & $\mathrm{~B}$ \\
\hline Available $\mathrm{P}(\mu \mathrm{g} / \mathrm{g})$ & $\begin{array}{l}F_{2,9}=9.28 \\
P=0.006\end{array}$ & 66.33 & \pm & 8.63 & A & 48.15 & \pm & 8.63 & A & 14.54 & \pm & 8.63 & $\mathrm{~B}$ \\
\hline Aggregate MWD (mm) & $\begin{array}{l}F_{2,9}=308.01 \\
P<0.001\end{array}$ & 0.36 & \pm & 0.06 & A & 0.79 & \pm & 0.06 & B & 2.46 & \pm & 0.06 & $\mathrm{C}$ \\
\hline$\%$ Macroaggregates (> $150 \mathrm{um}$ ) & $\begin{array}{l}F_{2,9}=114.51 \\
P<0.001\end{array}$ & 24.52 & \pm & 2.55 & A & 45.51 & \pm & 2.55 & B & 78.63 & \pm & 2.55 & $\mathrm{C}$ \\
\hline Bulk Density $\left(\mathrm{g} / \mathrm{cm}^{3}\right)$ & $\begin{array}{l}F_{2,9}=7.30 \\
P=0.013\end{array}$ & 1.39 & \pm & 0.04 & A & 1.31 & \pm & 0.04 & A & 1.19 & \pm & 0.04 & B \\
\hline
\end{tabular}

PLFA biomass represents total phospholipid fatty acid (PLFA) biomarker concentration, PLFA fungi:bacteria represents the ratio of PLFA fungi and bacteria biomarker concentrations, PLFA AMF biomass represents arbuscular mycorrhizal fungi (AMF) biomarker concentration, plant available $\mathrm{N}$ represents $0.01 \mathrm{~N} \mathrm{KCl}$ extractable $\mathrm{N}$, available $\mathrm{P}$ represents Bray-1 P, aggregate MWD represents aggregate mean weight-diameter, \% macroaggregates represents the percent of macroaggregates by mass, and bulk density represents the soil bulk density using a coring method. Different letters accompanying mean values indicate significant differences between treatment factors $(\alpha=0.05)$.

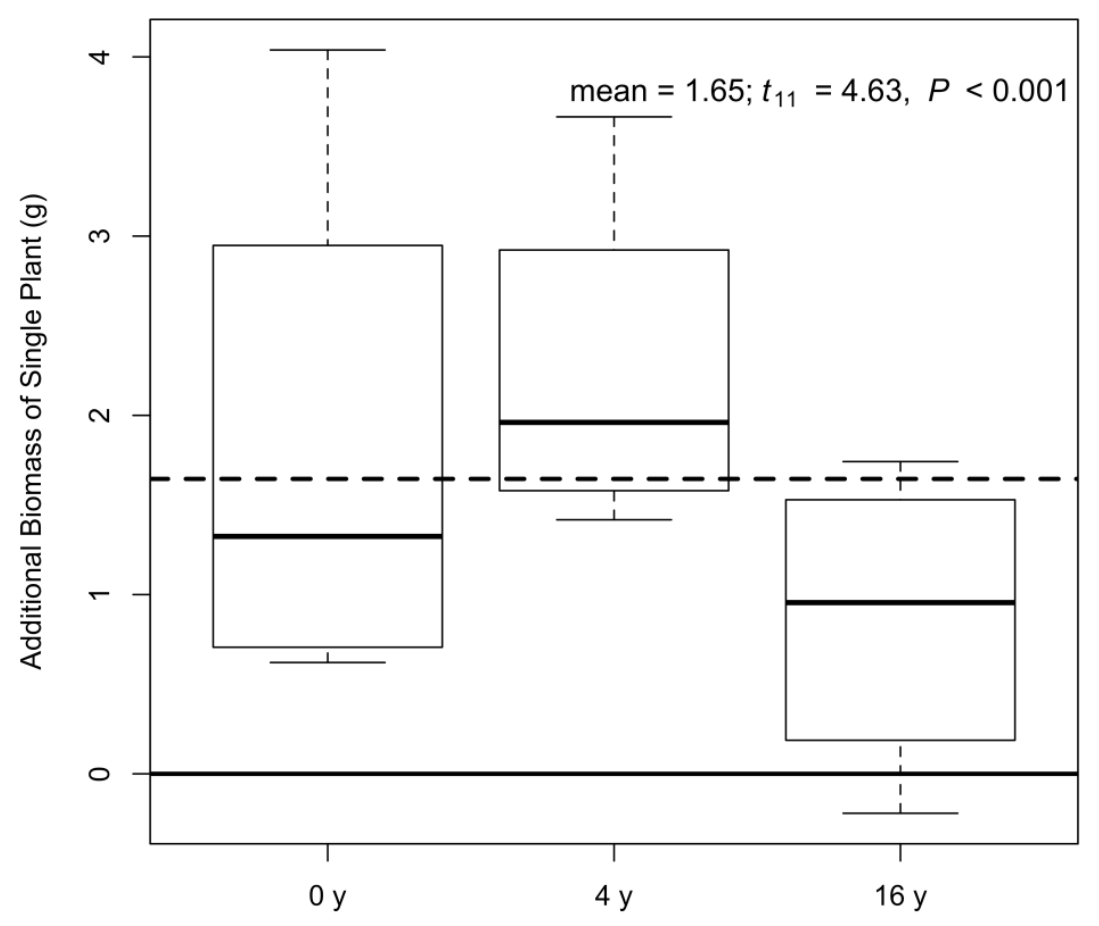

Figure 1. Boxplots of additional biomass produced by Andropogon gerardii grown alone as compared to per plant biomass produced by a two-individual monoculture of $A$. gerardii

The line at zero represents no competition (solid); positive values indicate competition. The global mean considering all soil restoration ages is represented with a dashed line. The mean, $t$ statistic, and $P$ value for a one-sample $t$ test with an alternative hypothesis of mean $>0$ is presented. 


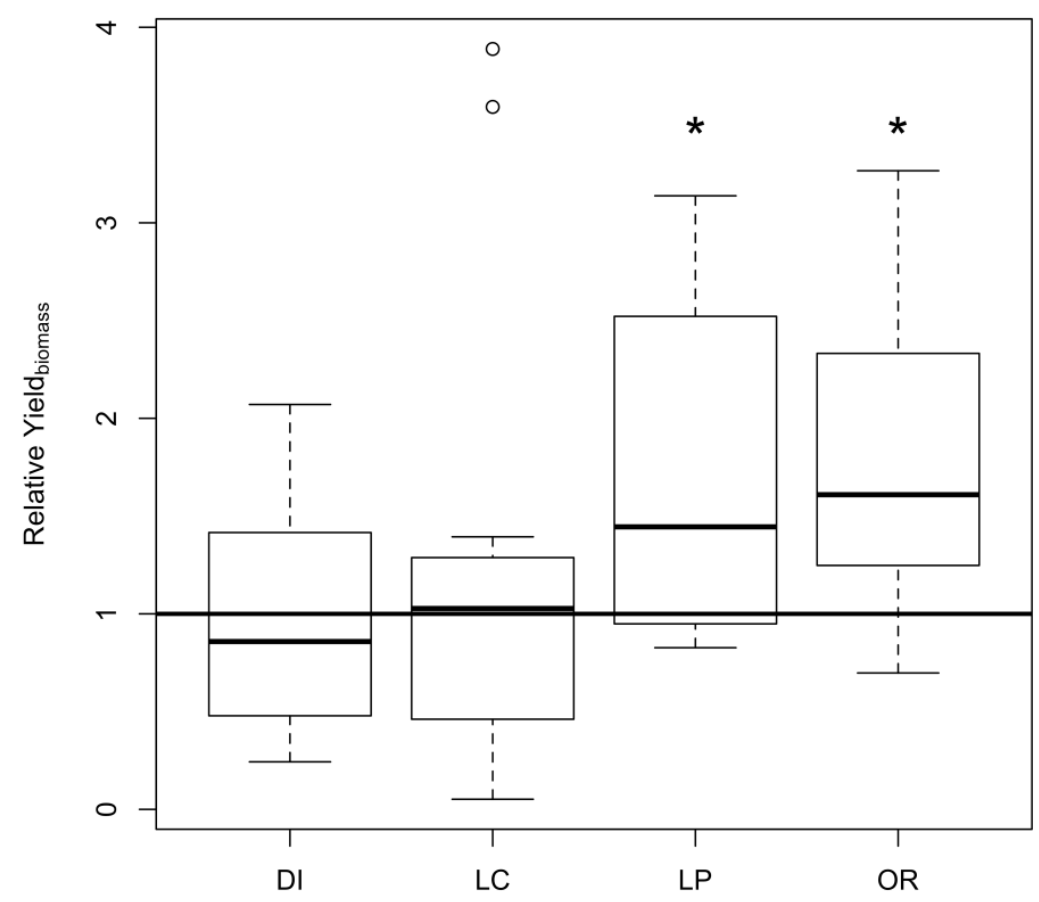

Figure 2. Boxplots of Relative Yield (RY) based on biomass with the focal grass, Andropogon gerardii

A solid line represents RY =1; a RY value above 1 indicates overyielding. Andropogon gerardii competition with a forb that resulted in RY greater than 1, according to a one-sample t-test, was marked with an *. Abbreviations: DI Desmanthus illinoensis, LC Lespedeza capitata, LP Liatris punctata, OR Oligoneuron rigidum.

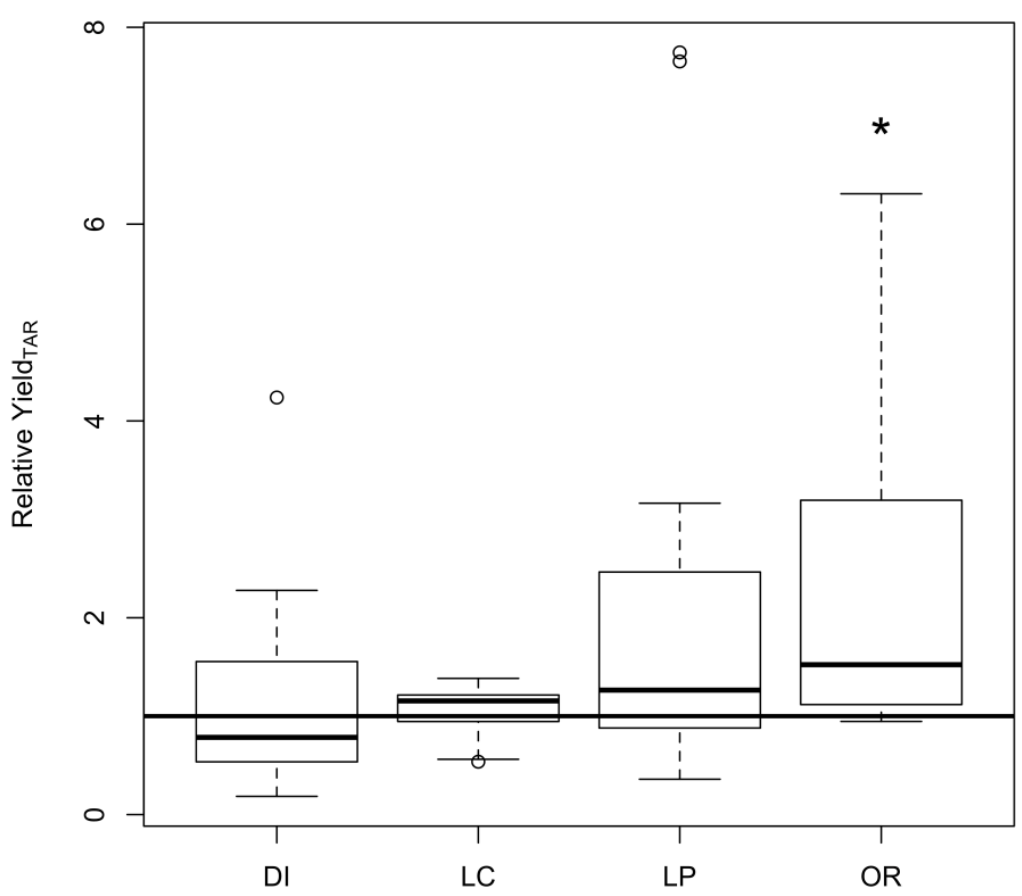

Figure 3. Boxplots of Relative Yield (RY) based on net absolute tiller appearance rate (TAR) with the focal grass, Andropogon gerardii

A solid line represents RY =1; a RY value above 1 indicates overyielding. Andropogon gerardii competition with a forb that resulted in RY greater than 1, according to a one-sample t-test, was marked with an *. Abbreviations are the same as in Figure 2. 


\section{Discussion}

Choosing an appropriate seed mix for grassland restoration remains a challenge. Response surface regression has suggested that 35 species in a seed mix with a moderately high seeding rate provides the greatest restoration success, at least in the short term (Barr et al., 2017). However, the Barr et al., analysis did not examine plant diversity in the longer term, where plant is expected to decrease due to increased cover of dominant grasses (Sluis, 2002; Camill et al., 2004; Hansen \& Gibson, 2014). Results from this competition experiment suggest that some common forbs (e.g. Liatris punctata and Oligoneuron rigidum) could promote overyielding of the dominant grass, A. gerardii, during tallgrass prairie restoration. These species should be given low-priority for inclusion in seed mixes. The pairwise competition across soils of differing restoration ages presented in this study provides a novel way to screen for suitable forb species for grassland restoration.

While the current study provides a screening method for species prioritization, it is important to note some limitations. This does not account for non-equilibrium dynamics that are expected to influence plant diversity in grassland systems due to drivers such as grazing, fire, climatic fluctuations (Soussana \& Lafarge, 1998). Despite these limitations, this study provides a method for choosing species that will not promote overyielding of a dominant grass.

\section{Acknowledgments}

Patrick Harris and Tianjiao Adams assisted with fieldwork. Amanda Rothert assisted with lab work. John Miller managed greenhouse conditions. Funding was provided through the National Science Foundation (DEB 1440484).

\section{References}

Barr, S., Jonas, J. L., \& Paschke, M. W. (2017). Optimizing seed mixture diversity and seeding rates for grassland restoration. Restoration Ecology, 25, 396-404. https://doi.org/10.1111/rec.12445

Beckage, B., \& Gross, L. J. (2006). Overyielding and species diversity: what should we expect?. New Phytologist, 172, 14-148. https://doi.org/10.1111/j.1469-8137.2006.01817.x

Camill, P., McKone, M. J., Sturges, S. T., Severud, W. J., Ellis, E., Limmer, J., ... Trout, A. (2004). Communityand ecosystem-level changes in a species-rich tallgrass prairie restoration. Ecological Application, 14, 1680-1694. https://doi.org/10.1890/03-5273

De Wit, C. T. (1960). On competition. Verslagen Landbouwkundige Onderzoekingen, 66, 1-82.

Hansen, M. J., \& Gibson, D. J. (2014). Use of multiple criteria in an ecological assessment of a prairie restoration chronosequence. Applied Vegetation Science, 17, 63-73. https://doi.org/10.1111/avsc.12051

Hector, A., Schmid, B., Beierkuhnlein, C., Caleira, M. C., Diemer, M., Dimitrakopoulos, P. G., ... Mulder, C. P. H. (1999). Plant diversity and productivity experiments in European grasslands. Science, 286, 1123-1127. https://doi.org/10.1126/science.286.5442.1123

Hening, A., \& Nguyen, D. H. (2018). Coexistence and extinction for stochastic Kolmogorov systems. Annals of Applied Probability, 28, 1893-1942. https://doi.org/10.1214/17-AAP1347

Kassambara, A. (2018). ggpubr: 'ggplot2' Based Publication Ready Plots. R package version 0.2. Retrieved from https://CRAN.R-project.org/package=ggpubr

Loreau, M., \& Hector, A. (2001). Partitioning selection and complementarity in biodiversity experiments. Nature, 412, 72-76. https://doi.org/10.1038/35083573

Manning, G. C., \& Baer, S. G. (2018). Interannual variability in climate effects on community assembly and ecosystem functioning in restored prairie. Ecosphere, 9, e02327. https://doi.org/10.1002/ecs2.2327

Myers, J. A., \& Harms, K. E. (2011). Seed arrival and ecological filters interact to assemble high-diversity plant communities. Ecology, 92, 676-686. https://doi.org/10.1890/10-1001.1

Rosenzweig, S., Carson, M., Baer, S. G., \& Blair, J. M. (2016). Changes in soil properties, microbial biomass, and fluxes of $\mathrm{C}$ and $\mathrm{N}$ in soil following post-agricultural grassland restoration. Applied Soil Ecology, 100, 186-194. https://doi.org/10.1016/j.apsoil.2016.01.001

Scott, D. A., Baer, S. G., \& Blair, J. M. (2017). Recovery and relative influence of root, microbial, and structural properties of soil on physically sequestered carbon stocks in restored grassland. Soil Science Society of America Journal, 81, 50-60. https://doi.org/10.2136/sssaj2016.05.0158

Scott, D. A., \& Baer, S. G. (2018). Degraded soil increases the performance of a dominant grass, Andropogon 
gerardii (Big bluestem). Plant Ecology, 219, 901-911. https://doi.org/10.1007/s11258-018-0844-0

Scott, D. A., \& Baer, S. G. (2019). Diversity patterns from sequentially restored grasslands support the 'environmental heterogeneity hypothesis'. Oikos, 128, 1116-1122. https://doi.org/10.1111/oik.05877

Sluis, W. J. (2002). Patterns of species richness and composition in re-created grassland. Restoration Ecology, 10, 677-684. https://doi.org/10.1046/j.1526-100X.2002.01048.x

Soussana, J.-F., \& Lafarge, M. (1998). Competition for resources between neighbouring species and patch scale vegetation dynamics in temperate grasslands. Annales de zootechnie, 47, 371-382. https://doi.org/10.1051/animres:19980505

The R Foundation for Statistical Computing. (2017). R version 3.4.2 (2017-09-28) “Short Summer". Platform: x86_64-ap- ple-darwin10.8.0 (64-bit).

Tilman, D., Reich, P. B., Knops, J., Wedin, D., Mielke, T., \& Lehman, C. (2001). Diversity and productivity in a long-term grassland experiment. Science, 294, 843-845. https://doi.org/10.1126/science.1060391

United States Department of Agriculture, Natural Resource Conservation Service. (2014). The PLANTS Database (http://plants.usda.gov, 9 June 2014). National Plant Data Team, Greensboro, NC 27401-4901 USA.

United States Department of Agriculture, Natural Resource Conservation Service, National Cooperative Soil Survey. Reading Series [Internet]. MLRA soil survey regional office responsible: Denver(CO). Retrieved from https://soilseries.sc.egov.usda. gov/OSD_Docs/R/READING.html

United States Department of Agriculture, Natural Resources Conservation Service, Soil Survey Staff. Web Soil Survey. Retrieved from http://websoilsurvey.nrcs.usda.gov

Weigelt, A., \& Jolliffe, P. (2003). Indices of plant competition. Journal of Ecology, 91, 707-720. https://doi.org/10.1046/j.1365-2745.2003.008

\section{Copyrights}

Copyright for this article is retained by the author(s), with first publication rights granted to the journal.

This is an open-access article distributed under the terms and conditions of the Creative Commons Attribution license (http://creativecommons.org/licenses/by/3.0/). 